\title{
Antibacterial and Antibiofilm Activity of Methanolic Plant Extracts against Nosocomial Microorganisms
}

\author{
Eduardo Sánchez, ${ }^{1}$ Catalina Rivas Morales, ${ }^{1}$ Sandra Castillo, ${ }^{2}$ Catalina Leos-Rivas, \\ Ledy García-Becerra, ${ }^{1}$ and David Mizael Ortiz Martínez ${ }^{1}$ \\ ${ }^{1}$ Departamento de Química, Facultad de Ciencias Biológicas, Universidad Autónoma de Nuevo León, \\ Ciudad Universitaria, 66451 San Nicolás de los Garza, NL, Mexico \\ ${ }^{2}$ Departamento de Alimentos, Facultad de Ciencias Biológicas, Universidad Autónoma de Nuevo León, \\ Ciudad Universitaria, 66451 San Nicolás de los Garza, NL, Mexico \\ Correspondence should be addressed to Eduardo Sánchez; eduardo.sanchezg@uanl.mx
}

Received 23 January 2016; Revised 16 May 2016; Accepted 9 June 2016

Academic Editor: Serkan Selli

Copyright (C) 2016 Eduardo Sánchez et al. This is an open access article distributed under the Creative Commons Attribution License, which permits unrestricted use, distribution, and reproduction in any medium, provided the original work is properly cited.

Biofilm is a complex microbial community highly resistant to antimicrobials. The formation of biofilms in biotic and abiotic surfaces is associated with high rates of morbidity and mortality in hospitalized patients. New alternatives for controlling infections have been proposed focusing on the therapeutic properties of medicinal plants and their antimicrobial effects. In the present study the antimicrobial and antibiofilm activities of 8 methanolic plant extracts were evaluated against clinical isolated microorganisms. Preliminary screening by diffusion well assay showed the antimicrobial activity of Prosopis laevigata, Opuntia ficus-indica, and Gutierrezia microcephala. The minimum inhibitory concentration (MIC) and minimum bactericidal concentration (MBC) were determined ranging from 0.7 to $>15 \mathrm{mg} / \mathrm{mL}$. The specific biofilm formation index (SBF) was evaluated before and after the addition of plant extracts $(\mathrm{MBC} \times 0.75)$. Opuntia ficus-indica caused the major reduction on SBF in dose-dependent manner. Cytotoxic activity of plant extracts was determined using brine shrimp lethality test (Artemia salina L.). Lethal Dose concentration ( $\mathrm{LD}_{50}$ values) of the plant extracts was calculated. $\mathrm{LD}_{50}$ values for P. laevigata and G. microcephala were 141.6 and $323.3 \mu \mathrm{g} / \mathrm{mL}$, respectively, while O. ficus-indica showed a slight lethality with $939.2 \mu \mathrm{g} / \mathrm{mL}$. Phytochemical analyses reveal the presence of flavonoids, tannins, and coumarines.

\section{Introduction}

Microbial biofilms are communities of bacteria, embedded in a self-producing matrix, forming on living and nonliving solid surfaces [1]. Biofilm-associated cells have the ability to adhere irreversibly on a wide variety of surfaces, including living tissues and indwelling medical devices as catheters, valves, prosthesis, and so forth [2].

They are considered an important virulence factor that causes persistent chronic and recurrent infections; they are highly resistant to antibiotics and host immune defenses [3]. Bacteria protected within biofilm exopolysaccharides are up to 1,000 times more resistant to antibiotics than planktonic cells (free-floating) [4], which generates serious consequences for therapy and severely complicates treatment options [5]. An estimated 75\% of bacterial infections involve biofilms that are protected by an extracellular matrix [6].

Biofilm resistance is due to several reasons, like restricted diffusion of antibiotics into biofilm matrix, expression of multidrug efflux pumps, type IV secretion systems, decreased permeability, and the action of antibiotic-modifying enzymes [7]. The increased biofilm resistance to conventional treatments enhances the need to develop new control strategies [8].

Biofilm inhibition is considered as major drug target for the treatment of various bacterial and fungal infections, and pharmacological development of this drugs is now extensively studied [9]. In recent years, several green nonlethal strategies for biofilm control have been developed, because the mode of action of these novel antibiofilm agents is 
TABLE 1: Overview of the collected plants used in this investigation.

\begin{tabular}{|c|c|c|c|c|}
\hline Scientific name & Common name & Family & Part used & Voucher number \\
\hline $\begin{array}{l}\text { Sophora secundiflora (Ortega) Lag. Ex } \\
\text { DC. }\end{array}$ & Mountain laurel & Fabaceae & Aerial parts & 027770 \\
\hline Sphaeralcea ambigua A. Gray & Desert globemallow & Malvaceae & Bark & 027771 \\
\hline $\begin{array}{l}\text { Prosopis laevigata (Humb. et Bonpl. ex } \\
\text { Willd) M.C. Johnston }\end{array}$ & Smooth mesquite & Fabaceae & Bark and leaves & 027772 \\
\hline Opuntia ficus-indica Mill. & Nopal cactus & Cactaceae & Cladode & 027773 \\
\hline Marrubium vulgare $\mathrm{L}$. & White horehound & Lamiaceae & Aerial parts & 027774 \\
\hline Scutellaria drummondii Benth & Drummond's skullcap & Lamiaceae & Aerial parts & 027775 \\
\hline Nothoscordum bivalve Britton. & Crowpoison & Alliaceae & Bulb & 027776 \\
\hline Gutierrezia microcephala (DC.) Gray & Sticky snakeweed & Asteraceae & Aerial parts & 027777 \\
\hline
\end{tabular}

much less susceptible to the emergence of resistance [10]. However although they are promising strategies, they have disadvantages because none have been totally effective [5].

One promising alternative is the search for naturally occurring compounds of plant origin capable of blocking biofilm formation [11]. Historically, plant extracts and their biologically active compounds have been a valuable source of natural products, which have played a central role in the prevention and treatment of diseases, helping to maintain human health [12]. Furthermore, they are widely accepted due to the perception that they are safe and have a long history of use in folk medicine to cure diseases and illnesses since ancient times [13].

Considering the above and based on previous results obtained in our laboratory, in the present study we propose to evaluate the antibiofilm effect of 8 extracts plants against 5 clinical isolated pathogens.

\section{Material and Methods}

2.1. Plant Material. Fresh and healthy plants growing wild around the Casablanca community, located in Santa Catarina, Nuevo León, Mexico ( $\left.25^{\circ} 39^{\prime} 11.33^{\prime \prime} \mathrm{N} 100^{\circ} 42^{\prime} 41.09^{\prime \prime} \mathrm{W}\right)$, were collected between March and April 2014. Voucher samples were deposited at the herbarium of the Botanical Department of Biological Sciences School, Universidad Autónoma de Nuevo León, for identification purposes. Collected plants (Table 1) were washed thoroughly in tap water, followed by successive washing in distilled water. Washed plants were cut into small pieces and air-dried at room temperature $\left(25 \pm 2^{\circ} \mathrm{C}\right)$ under shade. Finally, dried material was grounded to coarse powder in a manual grain mill and stored in plastic containers for further analysis.

2.2. Bacterial Strains and Culture Conditions. The microorganisms used in this study were 5 nosocomial pathogens, 4 Gram-negative (Klebsiella pneumoniae, Enterococcus faecalis, Escherichia coli, and Stenotrophomonas maltophilia) and 1 Gram-positive (Staphylococcus aureus). All strain were kindly provided by Dra. Elvira Garza Gomzález, School of Medicine, UANL. Strains were maintained in Mueller-Hinton
(MH) agar (Difco) at $4^{\circ} \mathrm{C}$. Active cultures were obtained by inoculation of a loopful of each strain into separated $5 \mathrm{~mL}$ $\mathrm{MH}$ broth (Difco) and incubated for $18 \mathrm{~h}$ at $37^{\circ} \mathrm{C}$.

2.3. Preparation of Plant Extracts. Extracts were prepared following the methodology proposed by Sánchez et al. [14], with minor modifications. Briefly, one hundred grams (100 g) of dried plant material was soaked with $500 \mathrm{~mL}$ of methanol for $24 \mathrm{~h}$ at room temperature $\left(25 \pm 2^{\circ} \mathrm{C}\right)$, under occasional shaking. Extraction was repeated three times, and the extracts obtained were combined and filtered through Whatman filter paper number 1 . After that, they were concentrated to dryness under reduced pressure using a rotary evaporator at $45^{\circ} \mathrm{C}$. Stock solutions $(200 \mathrm{mg} / \mathrm{mL})$ were prepared in methanol and stored at $4^{\circ} \mathrm{C}$ in the dark for further experiments.

2.4. Qualitative Phytochemical Screening. The extracts were subjected to standard phytochemical tests in order to evaluate their chemical composition for different active constituents; for this extracts $(3-5 \mathrm{mg} / \mathrm{mL})$ they were separately suspended in $1 \mathrm{~mL}$ of absolute ethanol or distilled water (carbohydrate determination) using clean test tubes.

2.5. Bayer's Test for Unsaturation. In this case aqueous $1 \%$ $\mathrm{KMnO}_{4}$ was added dropwise to the extract solution. A positive test was evidenced by the disappearance of the purple color of $\mathrm{KMnO}_{4}$ and the appearance of a brown solid precipitate $\left(\mathrm{MnO}_{2}\right)$ [15].

\subsection{Detection of Triterpenes/Steroids (Liebermann-Burchard} Reagent). One $\mathrm{mL}$ of acetic anhydride and 5 drops of concentrated sulfuric acid $\left(\mathrm{H}_{2} \mathrm{SO}_{4}\right)$ were added to the extract. A color change from violet to blue confirms the presence of steroids [16] and formation of blue-green ring indicated the presence of terpenoids [17].

2.7. Coumarins. Three $\mathrm{mL}$ of $2 \mathrm{~N} \mathrm{NaOH}$ was added to $2 \mathrm{~mL}$ of aqueous extract. Formation of yellow color indicated the presence of coumarins. Confirmation test was performed by adding $1 \mathrm{~mL}$ of $5 \mathrm{~N} \mathrm{HCl}$; in this case a colorless solution formed at the upper layer is considered positive [18]. 
2.8. Alkaloids. Ethanolic extracts $(20 \mu \mathrm{L})$ were applied on TLC plates (Silica Gel 60G, $5 \times 10 \mathrm{~cm}$ ) and eluted using toluene-ethyl acetate-diethylamine $(70: 20: 10)$ as solvent system. Alkaloids were detected after spraying Dragendorff's reagent as orange-brown spots on TLC plates [19].

2.9. Screening for Sesquiterpene Lactones. The Baljet reaction ( $1 \%$ Picric acid in $10 \%$ sodium hydroxide) was used to detect sesquiterpene lactones in the extracts. Reagents were mixed at a $1: 1$ ratio and added to $1 \mathrm{~mL}$ of extracts $(2-3 \mathrm{mg})$. The transformation of the sodium picrate solution's yellow color to orange-red color confirmed the positive reaction [20].

2.10. Test for Quinones. Extracts suspended in ethanol (1 mL) were treated with $1 \mathrm{~mL}$ of concentrated sulfuric acid. Formation of red color shows the presence of quinones [21].

2.11. Carboxyl Group. The presence of carboxyl groups was evidenced by adding 10 drops of $10 \%$ sodium bicarbonate solution; visible bubbles of carbon dioxide were considered a positive reaction [21].

2.12. Test for Tannins. Extracts were treated with $1 \mathrm{~mL}$ of $5 \%$ ferric chloride which was added. The presence of tannins was indicated by the formation of bluish black or greenish black precipitate [22].

2.13. Shinoda Test. Few fragments of magnesium metal ribbon (3-4 pieces) were added to $1 \mathrm{~mL}$ of ethanolic extract, followed by dropwise addition of concentrated hydrochloric acid. Formation of pink or red color indicated the presence of flavonoids [23].

2.14. Saponin. Two $\mathrm{mL}$ of distilled water was added to extracts suspended in ethanol and was shaken vigorously. The formation of copious foam layer indicates the presence of saponins [23].

2.15. Carbohydrates. For carbohydrates test, extracts (10 mg) were suspended in $1 \mathrm{~mL}$ of distilled water; afterward $2 \mathrm{~mL}$ of $0.2 \%$ anthrone reagent and 5 drops of concentrated sulfuric acid were added. Dark green color showed the presence of carbohydrates [21].

2.16. Evaluation of Antimicrobial Activity. Antimicrobial activity of plant extracts was performed using the agar-well diffusion bioassay. Briefly, $100 \mu \mathrm{L}$ of fresh culture (approximately $10^{6} \mathrm{CFU} / \mathrm{mL}$ ) was uniformly spread onto MuellerHinton agar (MHA) plates by sterile Driglasky loop. Then, inoculated plates were allowed to dry at room temperature for $20 \mathrm{~min}$. After that, wells of $6 \mathrm{~mm}$ in diameter were made in the agar using a sterilized cup-borer and $100 \mu \mathrm{L}$ of each extract was poured in the wells. Methanol was used as control. Plates were incubated at $37^{\circ} \mathrm{C}$ for $18 \mathrm{~h}$. Antibacterial activity was evidenced by the presence of clear inhibition zone around each well. The diameter of this zone was measured and recorded [14].
2.17. Assessment of Minimum Inhibitory Concentration (MIC) and Minimum Bactericidal Concentration (MBC). The MIC and $\mathrm{MBC}$ were determined on plant extracts that showed antimicrobial activity, by a broth microdilution method proposed by Novy et al. [24], with minor modifications. Briefly, $100 \mu \mathrm{L}$ of Mueller-Hinton Broth (Difco) plus different concentrations of plant extracts was prepared and transferred to each microplate well to obtain dilutions of the active extract, ranging from 1.0 to $25 \mathrm{mg} / \mathrm{mL}$. Then, $10 \mu \mathrm{L}$ of a fresh culture (final concentration of $1 \times 10^{6} \mathrm{CFU} / \mathrm{mL}$ ) of test organisms was added. Microplates were incubated at $37^{\circ} \mathrm{C}$ for $24 \mathrm{~h}$ [25]. MIC was defined as the lowest concentration of the extract that restricted the visible growth of microorganism tested.

To determine $\mathrm{MBC}, 100 \mu \mathrm{L}$ from each well that showed no visible growth was reinoculated on $\mathrm{MH}$ agar plates; then the plates were incubated at $37^{\circ} \mathrm{C}$ for $24 \mathrm{~h}$. MBC was defined as the lowest extract concentration showing no bacterial growth. Methanol was used as blank and tetracycline (Sigma Aldrich, Mexico City, Mexico) as positive control. Once the MBC was recorded, the sublethal activity on bacterial growth was determined; for this, concentrations of 75, 50, and 25\% of $\mathrm{MBC}$ were tested in a 96-well microplate and the counts of microbial cells were done by plate count technique, as previously mentioned.

2.18. Biofilm Formation Inhibition. The effect of extracts on biofilm formation was evaluated in 96-well polystyrene flatbottom plates [26]. Briefly, $300 \mu \mathrm{L}$ of inoculated fresh trypticase soy yeast broth (TSY) (final concentration $10^{6} \mathrm{CFU} / \mathrm{mL}$ ) was aliquoted into each well of microplate and cultured in presence of sublethal concentrations $(75,50$, and $25 \%$ of $\mathrm{MBC}$ ) previously determined. Wells containing medium and those without extracts and only with methanol were used as controls. Plates were incubated at $37^{\circ} \mathrm{C}$ for $48 \mathrm{~h}$. After incubation, supernatant was removed and each well was washed thoroughly with sterile distilled water to remove free-floating cells; thereafter plates were air-dried for $30 \mathrm{~min}$ and the biofilm formed was stained during $15 \mathrm{~min}$ at room temperature with $0.1 \%$ aqueous solution of crystal violet. Following incubation, the excess of stain was removed washing the plate three times with sterile distilled water. Finally, the dye bound to the cells was solubilized by adding $250 \mu \mathrm{L}$ of $95 \%$ ethanol to each well and after $15 \mathrm{~min}$ of incubation, absorbance was measured using microplate reader at a wavelength of $570 \mathrm{~nm}$. Biofilm determination was made using the formula $\mathrm{SBF}=$ $(\mathrm{AB}-\mathrm{CW}) / \mathrm{G}$, where SBF is the specific biofilm formation, $\mathrm{AB}$ is the OD570 $\mathrm{nm}$ of the attached and stained bacteria, CW is the OD570 $\mathrm{nm}$ of the stained control wells containing only bacteria-free medium, and G is the OD630 $\mathrm{nm}$ of cell growth in broth [27].

2.19. Toxicity Bioassay. Brine shrimp (Artemia salina) lethality bioassay was carried out in accordance with methodology proposed by Meyer et al. [28] to determine the toxicity of extract plants. For this, brine shrimps cysts were hatched in a shallow rectangular container, which was divided into two unequal compartments, filled with sterile artificial seawater 
TABLE 2: Diameter of inhibition zone of methanolic extracts against clinical isolated bacteria.

\begin{tabular}{|c|c|c|c|c|c|}
\hline \multirow{2}{*}{ Plant } & \multicolumn{5}{|c|}{ Inhibition zone $(\mathrm{cm})$} \\
\hline & K. pneumoniae & E. faecalis & E. coli & S. maltophilia & S. aureus \\
\hline S. secundiflora & NI & NI & NI & NI & $2.1 \pm 0.3$ \\
\hline S. ambigua & NI & NI & NI & $\mathrm{NI}$ & $1.2 \pm 0.1$ \\
\hline P. laevigata & $1.4 \pm 0.3$ & $1.7 \pm 0.3$ & $1.5 \pm 0.3$ & NI & $2.6 \pm 0.3$ \\
\hline O. ficus-indica & $1.7 \pm 0.1$ & $1.5 \pm 0.1$ & $1.6 \pm 0.3$ & NI & $1.6 \pm 0.3$ \\
\hline M. vulgare & $\mathrm{NI}$ & $0.7 \pm 0.01$ & NI & NI & $1.8 \pm 0.2$ \\
\hline S. drummondii & NI & $0.6 \pm 0.01$ & NI & NI & $1.7 \pm 0.2$ \\
\hline N. bivalve & $\mathrm{NI}$ & $\mathrm{NI}$ & $\mathrm{NI}$ & NI & NI \\
\hline G. microcephala & NI & $\mathrm{NI}$ & $1.6 \pm 0.1$ & NI & $2.3 \pm 0.2$ \\
\hline
\end{tabular}

Values are means \pm standard deviations. NI: no inhibition.

(prepared by dissolving sea salt $38 \mathrm{~g} / \mathrm{L}$ and adjusted to $\mathrm{pH} 8.5$ using $1 \mathrm{~N} \mathrm{NaOH}$ ) under constant aeration and proper light. Cyst (ca. $50 \mathrm{mg}$ ) was sprinkled into the larger compartment, which was darkened, while the smaller was illuminated. Yeast solution $0.06 \%$ was added to the hatching chamber to feed the larvae. After $48 \mathrm{~h}$ the phototropic free nauplii were collected from the lighted side.

Lethality bioassay was performed using 10 collected nauplii, which were transferred into vials contained tested crude plant extract, at 10,100, and $1000 \mu \mathrm{g} / \mathrm{mL}$, and artificial seawater. Appropriate quantities of methanol were used as negative control.

After $24 \mathrm{~h}$ of incubation, live nauplii were counted and the $\mathrm{LC}_{50}$ values were estimated using a Probit regression analysis. Extracts giving $\mathrm{LC}_{50}$ values above $1000 \mu \mathrm{g} / \mathrm{mL}$ were considered nontoxic.

2.20. Statistical Analysis. All experimental results were expressed as mean \pm standard deviation (SD) for analysis performed in duplicate at least three times. Statistical analysis of the data was performed by Analysis of Variance (ANOVA) and mean comparison using Student's $t$-test, using SPSS software version 17.0. The $\mathrm{LC}_{50}$ for bioassay with $A$. salina was determined according to the Probit statistical method. $P<0.05$ was considered statistically significant.

\section{Results and Discussion}

A total of 8 methanolic plant extracts were tested against 5 clinical bacterial isolates. Methanol was selected as extraction solvent, because it is one of the best solvents used for the extraction of antimicrobial substances [29, 30]. Moreover, methanol polarity ensured the extraction of polar and moderately polar active compounds from plants against microorganisms like terpenoids, tannins, flavones, and polyphenols [31].

Results of preliminary antimicrobial tests, performed by the well diffusion method, were quite variable between each plant extract ranging from 0 to $2.8 \mathrm{~cm}$ (Table 2). P. laevigata extract was active against all the clinical isolates, while $N$. bivalve bulb did not show activity against any microorganism. The highest diameter of inhibition was obtained with $P$. laevigata extract $(2.8 \pm 0.5 \mathrm{~cm})$, against $S$. aureus strain, followed by $G$. microcephala $(2.3 \pm 0.2 \mathrm{~cm})$ and $O$. ficus-indica $(1.6 \pm 0.3 \mathrm{~cm})$ also against $S$. aureus. Meanwhile E. coli was less susceptible to these extracts showing diameters of $1.7 \pm$ $0.3,1.4 \pm 0.1$, and $1.6 \pm 0.1 \mathrm{~cm}$, respectively. K. pneumoniae and $E$. faecalis were more resistant to the extracts, only inhibited by P. laevigata and O. ficus-indica with inhibition zones ranging from $0.7 \pm 0.08$ to $1.3 \pm 0.2$; on the other hand, S. maltophilia was the only microorganism that was not inhibited by the extracts.

However, the well diffusion assay is considered a qualitative technique and is mainly used for selecting extracts with antimicrobial activity, mostly when diameters zones of inhibition are $\geq 10 \mathrm{~mm}$ [32]. It is important to recognize that the size of inhibition zones of different extracts could be due to the compounds polarity obtained, since a more diffusible but less active extract could give a bigger diameter of inhibition than a nondiffusible but more active extract [33].

Minimum inhibitory concentration (MIC) results are comparable to those obtained in the agar-well diffusion technique, because the lowest MIC were obtained using the extracts showing the best antimicrobial activity (data not shown). Meanwhile results of minimum bactericidal concentrations (MBC) are listed in Table 3, where P. laevigata extract had the lowest $\mathrm{MBC}$ with a value of $2 \mathrm{mg} / \mathrm{mL}$ for $E$. coli, $2.8 \mathrm{mg} / \mathrm{mL}$ for E. faecalis, $3.8 \mathrm{mg} / \mathrm{mL}$ for K. pneumoniae, and $0.7 \mathrm{mg} / \mathrm{mL}$ for S. aureus. Extracts and O. ficus-indica got the highest $\mathrm{CMB}$ ranging from 1.0 to $\geq 15 \mathrm{mg} / \mathrm{mL}$. CMBs of G. microcephala were 2.8 and $8.3 \mathrm{mg} / \mathrm{mL}$ against $S$. aureus and $E$. coli, respectively. $\mathrm{MBC}$ results show that $S$. aureus was the more sensitive microorganism, being inhibited for 8 methanolic extracts, while S. maltophilia was not inhibited by any extract. Broadly, our results agree with previous reports, which mention greater activity of extracts towards Gram-positive microorganisms compared to Gram-negative microorganisms [34]. These differences can probably be attributed to the structural and compositional differences in the cell wall and membranes [25]. The Gram-negative bacteria have an outer membrane that serves as barrier for many molecules; also, the presence of efflux pump system has been demonstrated, which can mediate the resistance to natural compounds [35]. Escherichia coli was the most susceptible of the Gram-negative bacteria; this finding also agrees with previous reports [36]. 
TABLE 3: Minimum bactericidal concentration (MBC) of methanolic extracts against clinical isolated bacteria.

\begin{tabular}{|c|c|c|c|c|c|}
\hline \multirow{2}{*}{ Plant } & \multicolumn{5}{|c|}{$\mathrm{MBC}(\mathrm{mg} / \mathrm{mL})$} \\
\hline & K. pneumoniae & E. faecalis & E. coli & S. maltophilia & S. aureus \\
\hline S. secundiflora & $\mathrm{NE}$ & $\mathrm{NE}$ & $\mathrm{NE}$ & $\mathrm{NE}$ & $9.1 \pm 0.4$ \\
\hline S. ambigua & $\mathrm{NE}$ & $\mathrm{NE}$ & $\mathrm{NE}$ & $\mathrm{NE}$ & $>15$ \\
\hline P. laevigata & $3.8 \pm 0.1$ & $2.7 \pm 0.1$ & $1.5 \pm 0.2$ & $\mathrm{NE}$ & $0.7 \pm 0.01$ \\
\hline O. ficus-indica & $>15$ & $>15$ & $4.0 \pm 0.3$ & $\mathrm{NE}$ & $1.0 \pm 0.2$ \\
\hline M. vulgare & $\mathrm{NE}$ & $0.7 \pm 0.01$ & $\mathrm{NE}$ & $\mathrm{NE}$ & $3.9 \pm 0.3$ \\
\hline S. drummondii & $\mathrm{NE}$ & $0.6 \pm 0.01$ & $\mathrm{NE}$ & $\mathrm{NE}$ & $7.3 \pm 0.2$ \\
\hline N. bivalve & $\mathrm{NE}$ & $\mathrm{NE}$ & $\mathrm{NE}$ & $\mathrm{NE}$ & $\mathrm{NE}$ \\
\hline G. microcephala & $\mathrm{NE}$ & NE & $8.3 \pm 0.2$ & $\mathrm{NE}$ & $2.8 \pm 0.3$ \\
\hline
\end{tabular}

Values are means \pm standard deviations. NE: not evaluated.

TABLE 4: Phytochemical screening results of selected methanolic extracts.

\begin{tabular}{|c|c|c|c|}
\hline Compounds & P. laevigata & O. ficus-indica & G. microcephala \\
\hline Unsaturation & - & ++ & ++ \\
\hline Triterpenes/steroids & $++/$ Steroids & $++/$ Triterpenes & $+++/$ Triterpenes \\
\hline Coumarins & +++ & + & +++ \\
\hline Alkaloids & +++ & - & - \\
\hline Sesquiterpene lactones & - & - & ++ \\
\hline Quinones & - & + & + \\
\hline Carboxyl group & - & - & - \\
\hline Tannins & +++ & ++ & +++ \\
\hline Saponins & - & - & - \\
\hline Carbohydrates & ++ & +++ & - \\
\hline Flavonoids & ++ & + & ++ \\
\hline
\end{tabular}

+: low intensity reaction, ++: medium intensity reaction, and +++: strong intensity reaction.

According to the previously mentioned results, it was decided to select 3 plant extracts (P. laevigata, O. ficus-indica, and $G$. microcephala) which were active against E. coli (Gramnegative) and $S$. aureus (Gram-positive); moreover these extracts showed the lowest MBC.

Phytochemical screening results of selected plant extracts are summarized in Table 4 and show the presence of different functional groups. Coumarins, alkaloids, tannins, and flavonoids were found in $P$. laevigata extract. Similar compounds have been reported in different species of this plant like $P$. juliflora, where the presence of tannins, phenolics, flavonoids, steroids, terpenes, and alkaloids has been reported [37]. Likewise, reports of Prosopis spp. mentioned that this plant contains harmine, prosopine which is an alkaloid reported in several papers, tyramine, prosopinine, and juliflorine, which are alkaloids that intercalate into DNA and could explain the antimicrobial activity of this extract [31, 38].

In case of O. ficus-indica, results indicate the presence of triterpenes, coumarins, quinones, tannins, carbohydrates, and flavonoids; flavonoids cause bacterial death by inhibiting DNA or RNA synthesis and tannins including possible inhibition of extracellular microbial enzymes [39, 40].

Meanwhile, triterpenes, coumarins, quinones, tannins, flavonoids, and sesquiterpene lactones were found in $G$. microcephala. According to Gören et al. [41] sesquiterpene lactones are the main secondary metabolite responsible for the antimicrobial activity in Asteraceae family. While McDaniel and Ross [42] report the presence of alkaloids and saponins conferring some toxicity at this plant.

Biofilm formation inhibition results by addition of subinhibitory concentrations $(75,50$, and $25 \%$ of MBC) of plant extracts against $E$. coli and $S$. aureus indicated that the obtained effect was dose-dependent. The best biofilm reduction is observed in higher concentrations of the extracts $(75 \%$ of WBC). Similar results were reported by Issac Abraham et al. [43], who reported that methanolic caper extract significantly inhibited biofilm formation and EPS production in E. coli, Serratia marcescens, Pseudomonas aeruginosa, and Proteus mirabilis. As well Ravichandiran et al. [44] reported that ethanolic extract of the bark of Melia dubia caused a strong suppression of hemolysis, swarming motility, and biofilm formation in E. coli. Results of the effect of concentrations corresponding to 75 and $50 \%$ of MBC caused significant $(P<0.05)$ reduction of the specific biofilm formation $(\mathrm{SBF})$ of $E$. coli (Figure 1) from approximately 3 (strong biofilm) to levels of 0.2 (weak biofilm, 75\% MBC) and 1.2 (moderated biofilm, 50\% MBC). The SBF classification categories were mentioned by Mittal et al. [45] who mention that strong biofilm producers (SBF index $>2.00$ ), intermediate biofilm producers (SBF index between 1 and 2), and weak biofilm producers $(\mathrm{SBF}$ index $<1.00)$. Similar results were obtained with 


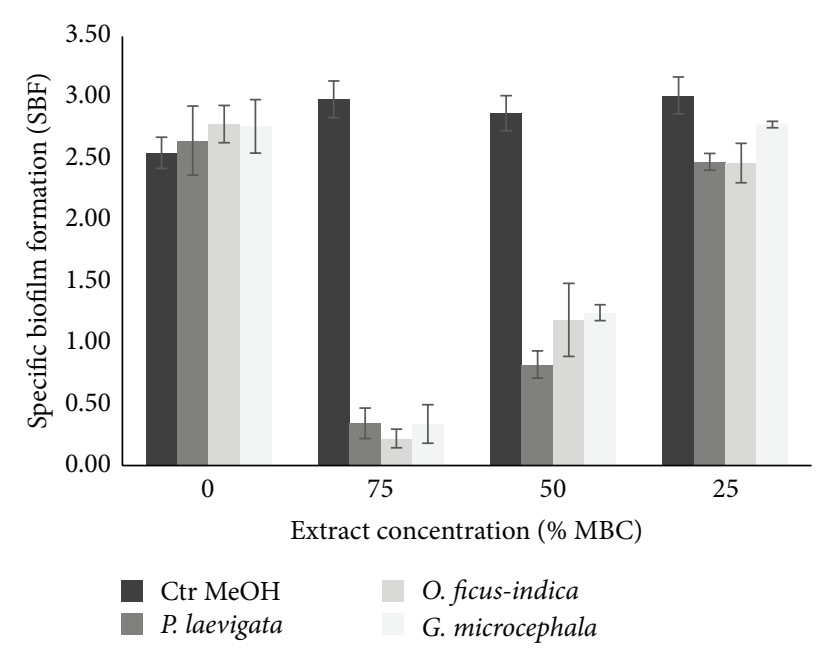

FIGURE 1: Inhibition of biofilm formation by different concentrations of plant extracts against E. coli.

S. aureus (data not shown). Inhibition of biofilm formation can be explained by the presence of flavonoids, previously reported such as quercetin, kaempferol, naringenin, and apigenin, which are capable of reducing biofilm synthesis because they can suppress the activity of the autoinducer- 2 responsible for cell-to-cell communication [46].

A. salina bioassay is used to evaluate the toxicity of plant extracts and has the advantage of being inexpensive, reliable, and reproducible [47]. In a previous study, Ahmed et al. [48] determined the toxicity of methanol extract of Prosopis spicigera reporting $60 \%$ survived nauplii at $100 \mu \mathrm{g} / \mathrm{mL}$ which is consistent with the results obtained in this work, because $\mathrm{LD}_{50}$ obtained of $P$. laevigata was $141.6 \mu \mathrm{g} / \mathrm{mL}$ indicating that the extract is moderately toxic; this may be due to the presence of certain bioactive compounds which may be related to the antibacterial activity. For G. microcephala was moderately toxic with $\mathrm{LD}_{50}$ of $323.3 \mu \mathrm{g} / \mathrm{mL}$, some studies mentioned that this toxicity may be due to the presence of saponins, essential oils, mono- and sesquiterpenes, tannins, and alkaloids $[42,49]$. Results of $O$. ficus-indica indicate slight toxicity $(939.2 \mu \mathrm{g} / \mathrm{mL})$; this is consistent as reported by Déciga-Campos et al. [50]. Low toxicity could be explained with the common use of this plant in traditional medicine. Furthermore, in vivo and in vitro experiments of cladodes and fruits show a beneficial effect on health due to the presence of flavonoids, which have health-related properties, which are based in their antioxidant activity $[51,52]$.

\section{Conclusions}

Some of the plant extracts evaluated in present research had potential antimicrobial and antibiofilm activities against isolated nosocomial bacteria, which can be an alternative to control the formation of microbial biofilms or can be used as model to the search for new drugs.

\section{Competing Interests}

The authors declare that they have no competing interests.

\section{Acknowledgments}

This work was supported by Programa de Investigación Científica y Tecnológica (PAICyT 2012), Universidad Autónoma de Nuevo León. The authors wish to express their gratitude to Dr. Jorge Armando Verduzco Martínez, for his excellent work in the identification of collected plants.

\section{References}

[1] R. Vasudevan, "Biofilms: microbial cities of scientific significance," Journal of Microbiology \& Experimentation, vol. 1, no. 3, pp. 1-16, 2014.

[2] M. R. Parsek and P. K. Singh, "Bacterial biofilms: an emerging link to disease pathogenesis," Annual Review of Microbiology, vol. 57, pp. 677-701, 2003.

[3] S. S. Grant and D. T. Hung, "Persistent bacterial infections, antibiotic tolerance, and the oxidative stress response," Virulence, vol. 4, no. 4, pp. 273-283, 2013.

[4] T. B. Rasmussen and M. Givskov, "Quorum-sensing inhibitors as anti-pathogenic drugs," International Journal of Medical Microbiology, vol. 296, no. 2-3, pp. 149-161, 2006.

[5] F. Sun, F. Qu, Y. Ling et al., "Biofilm-associated infections: antibiotic resistance and novel therapeutic strategies," Future Microbiology, vol. 8, no. 7, pp. 877-886, 2013.

[6] D. J. Musk, D. A. Banko, and P. J. Hergenrother, "Iron salts perturb biofilm formation and disrupt existing biofilms of Pseudomonas aeruginosa," Chemistry and Biology, vol. 12, no. 7, pp. 789-796, 2005.

[7] M. N. Alekshun and S. B. Levy, "Molecular mechanisms of antibacterial multidrug resistance," Cell, vol. 128, no. 6, pp. 10371050, 2007.

[8] L. C. Simões, M. Simões, and M. J. Vieira, "Biofilm interactions between distinct bacterial genera isolated from drinking water," Applied and Environmental Microbiology, vol. 73, no. 19, pp. 6192-6200, 2007.

[9] S. K. R. Namasivayam, B. Beninton, B. Christo, S. M. Karthigai, K. Arun Muthu Kumar, and K. Deepak, "Anti-biofilm effect of biogenic silver nanoparticles coated medical devices against biofilm of clinical isolate of Staphylococcus aureus," Global Journal of Medical Research, vol. 13, no. 3, pp. 1-7, 2013.

[10] M. Simões, L. C. Simões, and M. J. Vieira, "A review of current and emergent biofilm control strategies," LWT-Food Science and Technology, vol. 43, no. 4, pp. 573-583, 2010.

[11] J. A. Lizana, S. López, A. Marchal, U. Serrano, D. Velasco, and M. Espinosa-Urgel, "Use of plant extracts to block bacterial biofilm formation," in High School Students for Agricultural Science Research, Proceedings of the 3rd Congress PIIISA, pp. 4350, 2013.

[12] P. Karuppiah and M. Mustaffa, "Antibacterial and antioxidant activities of Musa sp. leaf extracts against multidrug resistant clinical pathogens causing nosocomial infection," Asian Pacific Journal of Tropical Biomedicine, vol. 3, no. 9, pp. 737-742, 2013.

[13] T. Rasamiravaka, Q. Labtani, P. Duez, and M. El Jaziri, "The formation of biofilms by Pseudomonas aeruginosa: a review of the natural and synthetic compounds interfering with control mechanisms," BioMed Research International, vol. 2015, Article ID 759348, 17 pages, 2015.

[14] E. Sánchez, N. Heredia, and S. García, "Extracts of edible and medicinal plants damage membranes of Vibrio cholerae," Applied and Environmental Microbiology, vol. 76, no. 20, pp. 6888-6894, 2010. 
[15] A. Ghosh, A. Bandyopadhyay, P. Ghosh, and P. Chatterjee, "Evaluation of antibacterial potentiality of a Cyclopenta Naphthalene tetraol terpenoid isolated from Curcuma caesia Roxb," Journal of Botanical Science, vol. 3, no. 1, pp. 27-34, 2013.

[16] M. Boxi, Y. Rajesh, V. R. Kumar, B. Praveen, and K. Mangamma, "Extraction, phytochemical screening and in-vitro evaluation of anti-oxidant properties of Commicarpus chinesis (aqueous leaf extract)," International Journal of Pharma and Bio Science, vol. 1, no. 4, p. 547, 2010.

[17] A. B. Fawehinmi, H. Lawal, S. O. Etatuvie, and F. O. Oyedeji, "Preliminary phytochemical screening and antimicrobial evaluation of four medicinal plants traditionally used in Nigeria for skin infection," African Journal of Pure and Applied Chemistry, vol. 7, no. 2, pp. 44-49, 2013.

[18] S. J. P. Jacob and S. Shenbagaraman, "Evaluation of antioxidant and antimicrobial activities of the selected green leafy vegetables," International Journal of PharmTech Research, vol. 3, no. 1, pp. 148-152, 2011.

[19] H. Wagner and S. Bladt, Plant Drug Analysis. A Thin Layer Chromatography Atlas, Springer, New York, NY, USA, 2nd edition, 2001.

[20] M. A. B. Aziz, "Qualitative phytochemical screening and evaluation of anti-inflammatory, analgesic and antipyretic activities of Microcos paniculata barks and fruits," Journal of Integrative Medicine, vol. 13, no. 3, pp. 173-184, 2015.

[21] X. A. Dominguez, Métodos en Investigación Fitoquímica, LIMUSA, 1973.

[22] S. Firdouse and P. Alam, "Phytochemical investigation of extract of Amorphophallus campanulatus tubers," International Journal of Phytomedicine, vol. 3, no. 1, pp. 32-35, 2011.

[23] S. K. Rathore, S. Bhatt, S. Dhyani, and A. Jain, "Preliminary phytochemical screening of medicinal plant Ziziphus mauritiana Lam fruits," International Journal of Current Pahrmaceutical Research, vol. 4, no. 3, pp. 160-162, 2012.

[24] P. Novy, H. Davidova, C. S. Serrano-Rojero, J. Rondevaldova, J. Pulkrabek, and L. Kokoska, "Composition and antimicrobial activity of Euphrasia rostkoviana Hayne essential oil," EvidenceBased Complementary and Alternative Medicine, vol. 2015, Article ID 734101, 5 pages, 2015.

[25] P. A. Lambert, "Cellular impermeability and uptake of biocides and antibiotics in gram-positive bacteria and mycobacteria," Journal of Applied Microbiology, vol. 92, supplement, pp. 46S54S, 2002.

[26] A. L. S. Antunes, D. S. Trentin, J. W. Bonfanti et al., "Application of a feasible method for determination of biofilm antimicrobial susceptibility in staphylococci," Acta Patologica, Microbiologica et Immunologica Scandinavica, vol. 118, no. 11, pp. 873-877, 2010.

[27] C. Niu and E. S. Gilbert, "Colorimetric method for identifying plant essential oil components that affect biofilm formation and structure," Applied and Environmental Microbiology, vol. 70, no. 12, pp. 6951-6956, 2004.

[28] B. N. Meyer, N. R. Ferrigni, J. E. Putnam, L. B. Jacobsen, D. E. Nichols, and J. L. McLaughlin, "Brine shrimp: a convenient general bioassay for active plants constituents," Journal of Medicinal Plants Research, vol. 45, pp. 31-34, 1982.

[29] V. C. Pérez-Nájera, E. C. Lugo-Cervantes, M. GutiérrezLomelí, and C. L. Del-Toro-Sánchez, "Extracción de compuestos fenólicos de la cáscara de lima (Citrus limetta risso) y determinación de su actividad antioxidante," Biotecnia, vol. 15, no. 3, pp. 18-22, 2015.
[30] Y. Vaghasiya and S. V. Chanda, "Screening of methanol and acetone extracts of fourteen Indian medicinal plants for antimicrobial activity," Turkish Journal of Biology, vol. 31, no. 4, pp. 243-248, 2007.

[31] M. M. Cowan, "Plant products as antimicrobial agents," Clinical Microbiology Reviews, vol. 12, no. 4, pp. 564-582, 1999.

[32] A. Usman, F. I. Abdulrahman, and A. Usman, "Qualitative phytochemical screening and in vitro antimicrobial effects of methanol stem bark extract of Ficus thonningii (Moraceae)," African Journal of Traditional, Complementary and Alternative Medicines, vol. 6, no. 3, pp. 289-295, 2009.

[33] F. Savaroglu, S. Ilhan, and C. Filik-Iscen, "An evaluation of the antimicrobial activity of some Turkish mosses," Journal of Medicinal Plants Research, vol. 5, no. 14, pp. 3286-3292, 2011.

[34] I. C. Zampini, S. Cuello, M. R. Alberto et al., "Antimicrobial activity of selected plant species from 'the Argentine Puna' against sensitive and multi-resistant bacteria," Journal of Ethnopharmacology, vol. 124, no. 3, pp. 499-505, 2009.

[35] C. Wendakoon, P. Calderon, and D. Gagnon, "Evaluation of selected medicinal plants extracted in different ethanol concentrations for antibacterial activity against human pathogens," Journal of Medicinally Medicinal Plants, vol. 1, no. 2, pp. 60-68, 2012.

[36] D. L. Njimoh, J. C. N. Assob, S. E. Mokake, D. J. Nyhalah, C. K. Yinda, and B. Sandjon, "Antimicrobial activities of a plethora of medicinal plant extracts and hydrolates against human pathogens and their potential to reverse antibiotic resistance," International Journal of Microbiology, vol. 2015, Article ID 547156, 15 pages, 2015.

[37] S. Singh, "Phytochemical analysis of different parts of Prosopis juliflora," International Journal of Current Pharmacology Research, vol. 4, no. 3, pp. 59-61, 2012.

[38] A. Aqeel, A. K. Khursheed, A. Viqaruddin, and Q. Sabiha, "Antimicrobial activity of julifloricine isolated from Prosopis juliflora," Arzneimittel-Forschung, vol. 39, no. 6, pp. 652-655, 1989.

[39] K. Akiyama, H. Matsuoka, and H. Hayashi, "Isolation and identification of a phosphate deficiency-induced C-glycosylflavonoid that stimulates arbuscular mycorrhiza formation in melon roots," Molecular Plant-Microbe Interactions, vol. 15, no. 4, pp. 334-340, 2002.

[40] T. P. T. Cushnie and A. J. Lamb, "Antimicrobial activity of flavonoids," International Journal of Antimicrobial Agents, vol. 26, no. 5, pp. 343-356, 2005.

[41] N. Gören, H. J. Woerdenbag, and C. Bozok-Johansson, "Cytotoxic and antibacterial activities of sesquiterpene lactones isolated from Tanacetum praeteritum subsp. praeteritum," Planta Medica, vol. 62, no. 5, pp. 419-422, 1996.

[42] K. C. McDaniel and T. T. Ross, "Snakeweed: poisonous properties, livestock losses, and management considerations," Journal of Range Management, vol. 55, no. 3, pp. 277-284, 2002.

[43] S. V. P. Issac Abraham, A. Palani, B. R. Ramaswamy, K. P. Shunmugiah, and V. R. Arumugam, "Antiquorum sensing and antibiofilm potential of Capparis spinosa," Archives of Medical Research, vol. 42, no. 8, pp. 658-668, 2011.

[44] V. Ravichandiran, K. Shanmugam, K. Anupama, S. Thomas, and A. Princy, "Structure-based virtual screening for plant-derived SdiA-selective ligands as potential antivirulent agents against uropathogenic Escherichia coli," European Journal of Medicinal Chemistry, vol. 48, pp. 200-205, 2012. 
[45] R. Mittal, S. Sharma, S. Chhibber, S. Aggarwal, V. Gupta, and K. Harjai, "Correlation between serogroup, in vitro biofilm formation and elaboration of virulence factors by uropathogenic Pseudomonas aeruginosa," FEMS Immunology and Medical Microbiology, vol. 58, no. 2, pp. 237-243, 2010.

[46] A. Vikram, G. K. Jayaprakasha, P. R. Jesudhasan, S. D. Pillai, and B. S. Patil, "Suppression of bacterial cell-cell signalling, biofilm formation and type III secretion system by citrus flavonoids," Journal of Applied Microbiology, vol. 109, no. 2, pp. 515-527, 2010.

[47] J. L. McLaughlin, Ch. Chang, and D. L. Smith, Simple Bioassay for the Detection and Isolation of Bioactive Natural Products, Departament of Medicinal Chemistry and Pharmacognosy, School of Pharmacy and Pharmacal Sciences, Pardue University, West Lafayerre, Ind, USA, 1988.

[48] W. Ahmed, M. Ahmed, A. Rauf, S. Feroz, Z. Khan, and Z. U. Haq, "Phytochemistry and cytotoxicity of Prosopis spicigera using Brine Shrimp lethality assay," Topclass Journal of Herbal Medicine, vol. 3, no. 3, pp. 14-16, 2014.

[49] J. M. Kingsbury, Poisonous Plants of the United States and Canada, Prentice-Hall, Englewood Cliffs, NJ, USA, 1964.

[50] M. Déciga-Campos, I. Rivero-Cruz, M. Arriaga-Alba et al., "Acute toxicity and mutagenic activity of Mexican plants used in traditional medicine," Journal of Ethnopharmacology, vol. 110, no. 2, pp. 334-342, 2007.

[51] O. Benavente-García, J. Castillo, F. R. Marin, A. Ortuño, and J. A. Del Río, "Uses and properties of Citrus flavonoids," Journal of Agricultural and Food Chemistry, vol. 45, no. 12, pp. 4505-4515, 1997.

[52] G. Ginestra, M. L. Parker, R. N. Bennett et al., "Anatomical, chemical, and biochemical characterization of cladodes from prickly pear [Opuntia ficus-indica (L.) Mill.]," Journal of Agricultural and Food Chemistry, vol. 57, no. 21, pp. 10323-10330, 2009. 


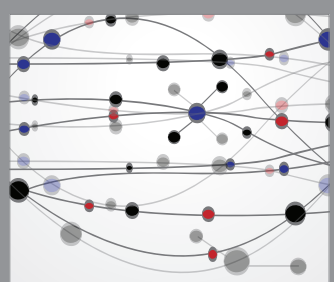

The Scientific World Journal
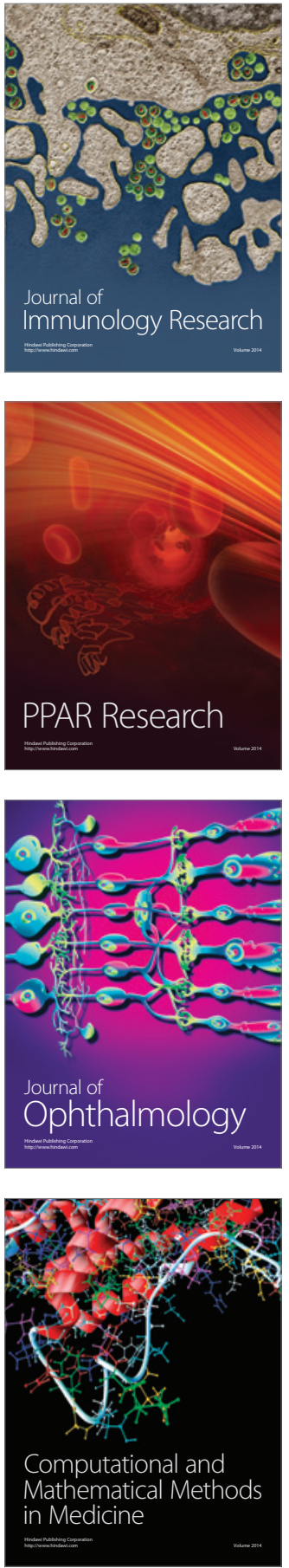

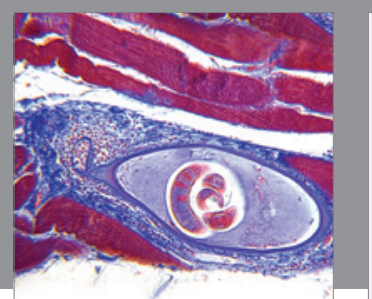

Gastroenterology Research and Practice

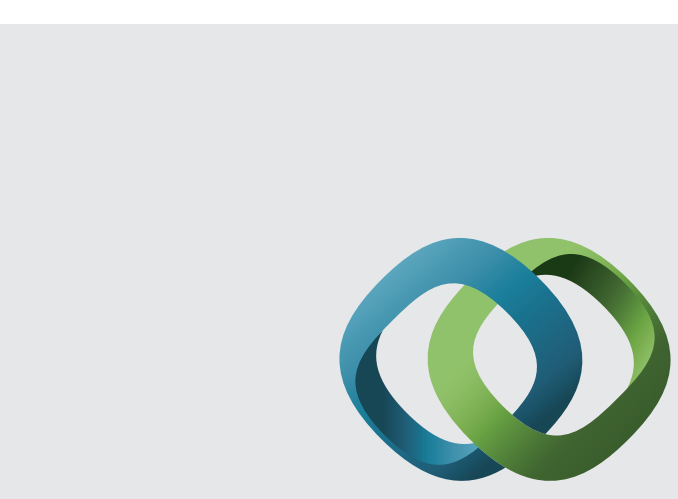

\section{Hindawi}

Submit your manuscripts at

http://www.hindawi.com
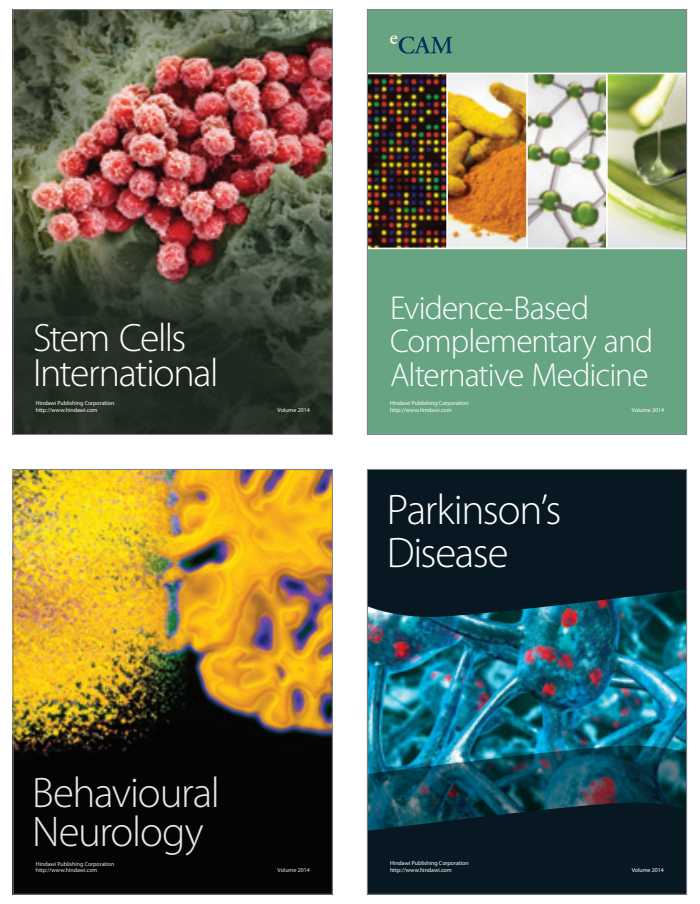
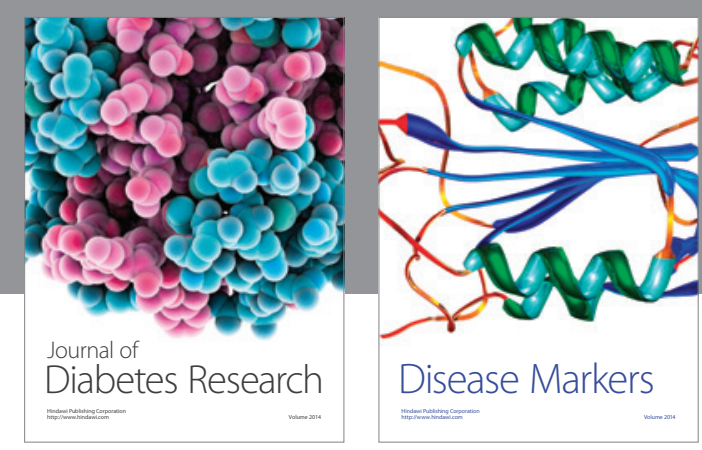

Disease Markers
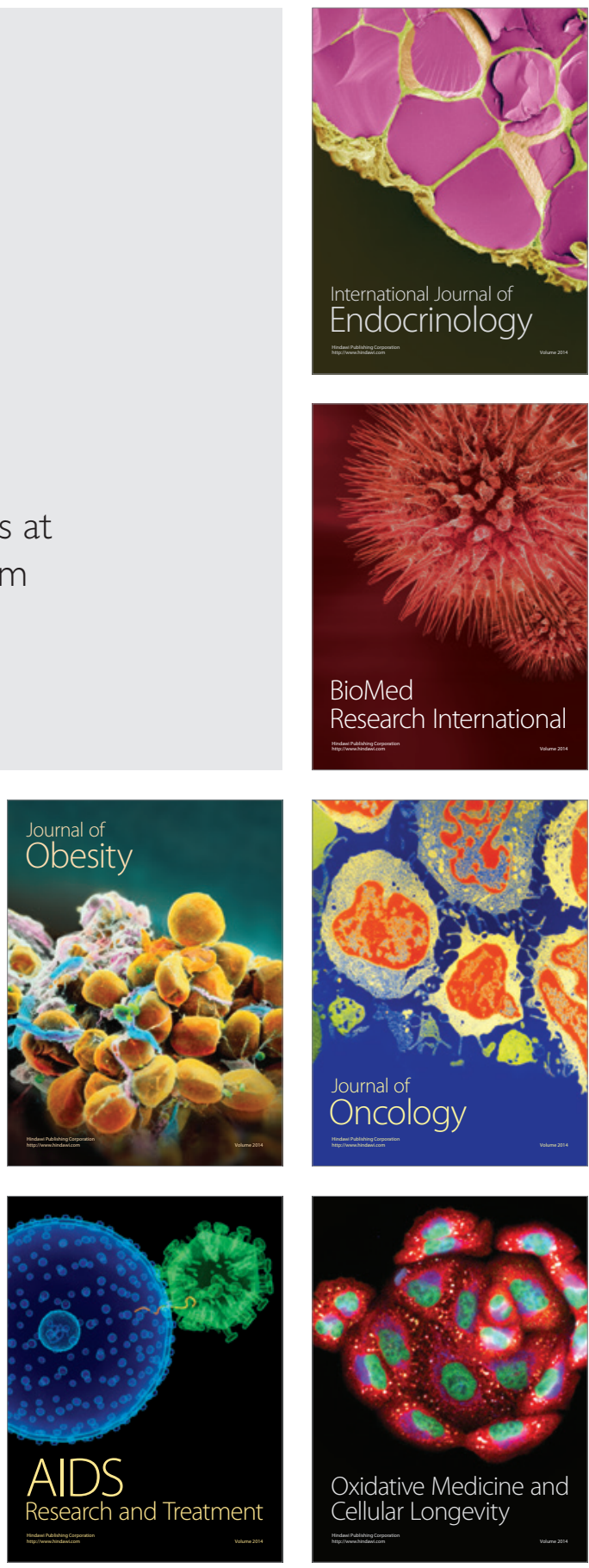